\title{
VISUALIZATION OF HORIZONTAL POSITIONALACCURACY ASSESSMENT RESULTS FOR DIGITAL TOPOGRAPHIC MAPS AT SCALE 1:25000
}

\author{
Siniša Drobnjak, \\ Radoje Banković1, \\ Saša Bakrač \\ Miodrag Kostić
}

${ }^{1}$ Military Geographical Institute, 5 Mije Kovačevića St., Belgrade, the Republic of Serbia ${ }^{2}$ Serbian Armed Forces, 38 Neznanog junaka St., Belgrade, the Republic of Serbia
Correspondence:

Siniša Drobnjak

e-mail:

sdrobnjak81@gmail.com

\begin{abstract}
:
The paper describes the visualization possibility of estimated results of horizontal positional accuracy of digital topographic map scale at 1:25 000 (DTM25) using geostatistical interpolation method. Estimation of horizontal positional accuracy DTM25 is realized by using standard STANAG 2215 (Standardization Agreement), which is intended for publishers of geotopographic material, or national mapping agencies for assessment of horizontal and vertical positional accuracy of spatial data by using ArcGIS software. The estimated results of horizontal positional accuracy are shown by means of a map that uses interpolated values of the root mean horizontal position.
\end{abstract}

Keywords:

Spatial data quality, Positional accuracy, STANAG 2215, Interpolation method, Kriging.

\section{INTRODUCTION}

Positional accuracy is one element of spatial data quality, which is defined as the accuracy of the position of features within a spatial reference system. Also, positional accuracy represents the nearness of those values to the entity`s "true" position in the coordinate system. It is the quality element of geographic information most often used by the national mapping agencies (NMAs) and also more commonly evaluated quality element option. It consists of three sub-elements of data quality [7], [14]:

- Absolute or external accuracy - closeness of reported coordinate values to values accepted as true, or being true;

- Relative or internal accuracy - closeness of the relative position of features in a data set to their respective relative positions accepted as true, or being true;

- Positional accuracy of gridded data - closeness of gridded data spatial position values to values accepted as true, or being true.

Visualization approaches of horizontal positional accuracy assessment results have been developed for different purposes, audiences, and levels of interactivity. These approaches, which can be classified into static mode and dynamic mode, have application potential for visualizing uncertainties in spatial data and analyses of digital topographic maps. In this paper, we use color map method for visualization results of horizontal accuracy assessment [4]. 
Evaluation of the accuracy is reduced to a comparison of coordinates of individual points read from maps with a reference. Reference data sets have several times more accurate coordinates of the correspondent points. Reference data sets are positioned using geodetic measurements in the field or taken from other more accurate sources. The basic problem in assessing positional accuracy of maps is the choice of accuracy measures (i.e. accuracy estimators), as well as a corresponding set of points that represent a chosen map sheet and the entire map [6].

Positional accuracy can be defined as the degree of proximity of an object, or as measuring it to its actual position, or to values in an appropriate reference system [3]. Positional accuracy is expressed through two variables that have a long history of use, and are a root mean square error and standard deviation [16].

\section{HORIZONTAL POSITIONAL ACCURACY ASSESSMENT}

Positional accuracy has been evaluated using control points. These points are defined as "well defined points", and their use has been conditioned by classical topographic field surveying methods. Following this idea there are many statistical Positional Accuracy Assessment Methodologies like [1]: NMAS [19], NSSDA [10], STANAG 2215 [15]. In addition, those methodologies represent point-based positional accuracy assessment methods and many of them are stated as standards for the positional control of cartographic products by national mapping agencies. Some of these methods have recently been analyzed in detail using a simulation process, and are compared by the same authors [9]. Nevertheless, researchers have criticized these standards for being limited to well defined points, and also for failing to address more complex elements like linear and polygon ones. It is not possible to assume that all features can be characterized by an error in the position of well-defined points [2].

On the other hand, the most widespread applied methods for the line-based positional accuracy assessment of 2D lines are the following: the Hausdorff Distance (HDM), the Mean Distance (MDM) [17], the Single Buffer Overlay (SBOM) [11] and the Double Buffer Overlay (DBOM) [18]. All abovementioned methods present an asymmetric or directional behavior, which means that results depend on direction of the assessment. The asymmetry comes from intervening elements when a distance estimation formula is applied. All results are understood as uniform errors along lines. We know that a distribution is non-uniform in line which is its limitation.
Quality method used in this paper represents pointbased positional accuracy assessment method. Quality measures of horizontal positional accuracy used in this research are the following:

- The root mean square error of planimetry (RMSEp) that is used in the Military Geographical Institute for the assessment of horizontal positional accuracy in earlier research;

- The circular error (circular map accuracy standard - CMAS) provided by the STANAG 2215 standard, with a $90 \%$ confidence level.

For the selected test area, projected coordinates of test points that had the content of sheet DTM25 were measured in eight sheets of digital topographic maps at a scale of 1:25000. Test points are point objects and nodes of line, or polygon features of the DTM25. Reference points are collected through fieldwork, during field checks using GPS, or with digital stereo restitution based on $3 \mathrm{D}$ photogrammetric stereo models. The process of collecting test points compared to the corresponding reference point was done by PAAT (Positional Accuracy Assessment Tool) ESRI ArcGIS software.

The PAAT uses the root mean square error for assessing the positional accuracy as the baseline, which is denoted by the RMSE (Root Mean Square Error). The RMSE is the second root of the mean sum of squared differences of coordinates, read from the map and the corresponding reference ("true") coordinates. The accuracy is communicated with nature-expressed coordinates (meter), which enables a direct comparison of different products, regardless of differences in scale or resolution [3]. The PAAT has the possibility of analyzing the two components of positional accuracy, a horizontal and vertical one (Figure 1).

In assessing positional accuracy, PAAT automatic testing and rejection of outliers are used. In this test statistics we used a value which represents the mean residual, plus three times the standard deviation, all being marked with the $3 \sigma$ threshold. Any residual value that is greater than the $3 \sigma$ threshold is considered to lie outside the valid values and the program automatically ejects this value, leaving the possibility of including these points [8].

The report on results of the analysis in positional accuracy using the PAAT consists of a text file for the appropriate test area. It consists of vector reference and test points data in a standard ESRI Shapefile and metadata in accordance with ISO 19115 and FGDC standards in the form of an XML file. Since the PAAT does not have an integrated analysis of positional accuracy based on the STANAG 2215 standard, the analysis results have been exported to Excel format. 


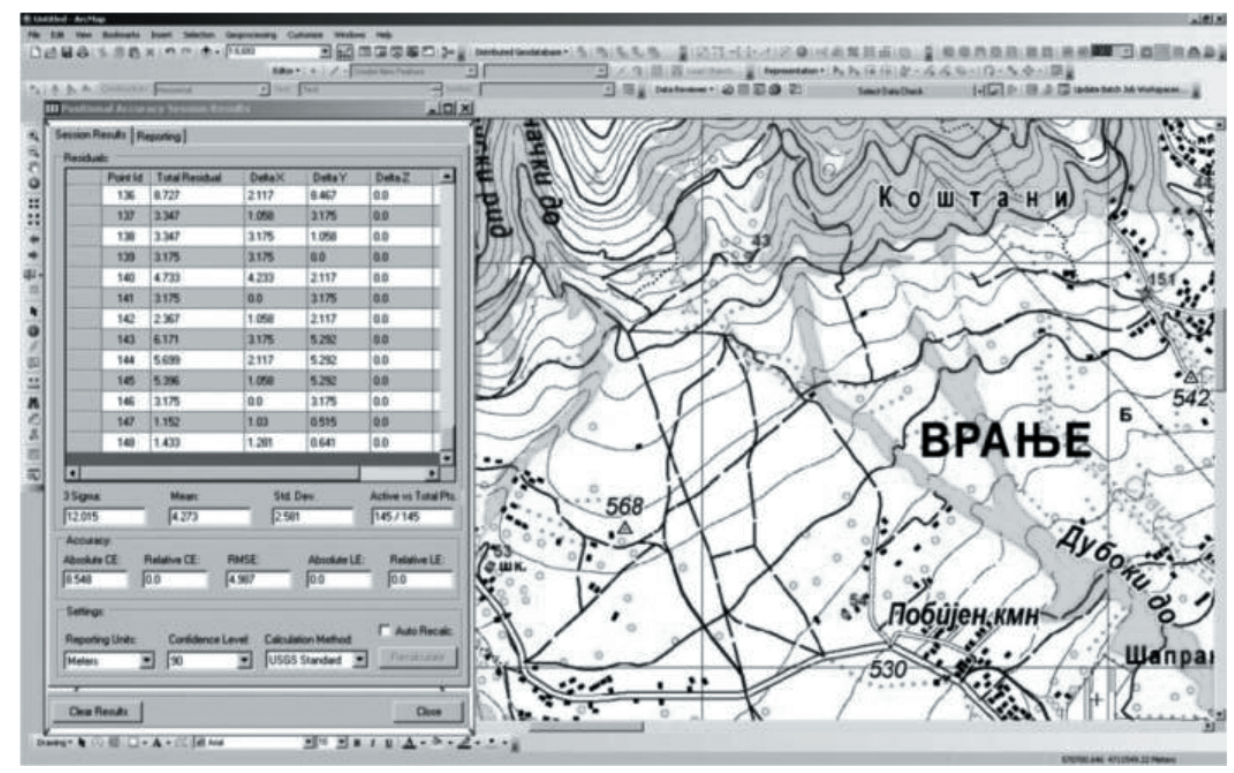

Fig. 1. Tools for analysing positional accuracy - PAAT.

In order to provide enough uniformly distributed and well defined test points for the analysis of positional accuracy, the PAAT includes the ability to divide the entire test area into a regular grid. By defining the number of rows and columns, we define the value of a single cell grid. After collecting the individual test points in relation to a reference point in a single cell grid, the program will automatically lead to the next cell of the grid [6]. In the experimental study, we defined 13 rows and 13 columns, which enable the test area to be divided into 169 equal-cell grid. Since the STANAG 2215 standard specifies that the minimal number of points in the analysis of positional accuracy should be 167, such gridded sampling has provided the test area with enough uniformly distributed well-defined points [15].

\section{GEOSTATISTICAL INTERPOLATION METHODS}

The positional accuracy assessment results of digital spatial data have great potential in visual display. It has already been mentioned that, in assessing the positional accuracy of the test area per the STANAG 2215 standard, at least 167 evenly spaced, well-defined diagnostic test points were used. For those, the value of the root mean square error of the horizontal points' position is shown graphically using the size of symbols. By using the method of interpolation, it is possible for each test area to get to the surface of the root mean square error of the horizontal points' position value. The most commonly used interpolation methods are:

- interpolation using movable surfaces (interpolation with local polynomials and the inverse distance method);

- the geostatistical interpolation method (Ordinary Kriging).

Theoretically, the fairest result in some of the surface modeling, based on measured values of the reference points, should be expected when using geostatistical methods, from which the most commonly used, is Kriging. The Kriging method is based on a treatment carried out by interpolation in accordance with the theory of regionalized variables. The basic idea of Kriging is to predict the value of a function at a given point by computing a weighted average of the known values of the function in the point's surrounding. For all types of Kriging, it is assumed that the modeled surface is represented in the generic form [13]:

$$
Z(s)=\mu(s)+\varepsilon(s)
$$

Where $\mu$ (s) trends the surface, while the $\varepsilon(\mathrm{s})$ is the surface, which is the result of a random process. Interpolation using the geostatistical method is performed in two steps:

- Quantification of the spatial structure of the surface that is modelled (based on input data) and

- Prediction, i.e. assessing the value of tool surface at given points. 
The quantification of the modelled spatial structure of the surface is performed by determining the empirical covariance function, which is a semivariogram describing the spatial dependence of the post of the surface points. The main problem with the practical application of these methods is the right choice of the appropriate covariance functions (semivariograms), i.e. selection of an appropriate model function and empirical determination of the parameters and functions.

The standard version of Kriging is called Ordinary Kriging (OK). Its predictors are based on a model [12]:

$$
Z(s)=\mu+\varepsilon^{\prime}(s)
$$

Where $\mu$ is a constant stationary function (global mean), and $\varepsilon^{\prime}(s)$ represents a spatially correlated stochastic part of variation. The result of the variable $\mathrm{Z}$ at a given location $s_{0}$ is a combination of sampled values [12]:

$$
\hat{Z}_{O K}\left(s_{0}\right)=\sum_{i=1}^{n} w_{i}\left(s_{0}\right) \cdot z\left(s_{i}\right)=\lambda_{0}^{T} \cdot z
$$

Where $\lambda_{0}$ is a vector of weight coefficients $\left(\mathrm{w}_{\mathrm{i}}\right)$ for Ordinary Kriging, and $z$ is a vector of available samples (measured values at specific locations). A semivariogram model is used to calculate the covariance matrix and vectors, which show the key sizes for achieving the optimal weight coefficients at any point in which a prediction is made. The system of equations, which provides weight coefficients $\mathrm{w}_{\mathrm{i}}$, is given in a matrix notation:

$$
\lambda_{o}=C^{-1} \cdot s
$$

Where $\mathrm{C}$ is the co-variation matrix between all sampled values, derived for $\mathrm{n} \times \mathrm{n}$ observations, and $\mathrm{c} 0$ being the vector of covariance between the sampled points and the point where the value is assessed.

Kriging is not limited to a simple estimate of the observed variable at a certain point, but this method can also[13]:

- Calculate the variance of the variable, which enables determination of the estimated size of confidence in intervals;

- Assess an average value of the variable in a section of the area,

- Determine the best location for a new measurement point before planning a network of measuring points.
The software program, which used ArcGIS in the process of the interpolation method, will be offered an opportunity to be cross validated in order to reach the optimal parameters for the selection of reference points. Cross Validation is used for quality assessment or validation of results to predict the applied method of interpolation. It is a process where the interpolation, using the selected parameters (and interpolation methods), interpolates desired value (predicted value) in a reference point, on the condition that the item is not taking part in the interpolation. Different measures and predicted values are to be made afterwards. The procedure is repeated for all locations at which the measurement was performed.

\section{RESULTS AND DISCUSSION}

Table 1 shows the parts of the Excel spreadsheet with the results of the positional accuracy assessment of the test area covered by a single sheet DTM25, nomenclature NK34-5/6-2-4 Vranje.

From the figures in the table it can be concluded that the value of the root mean square error planimetry (RMSEr) is 5,413 meters, while the average value of the horizontal position (dR) for that test area is 4,658 meters.

Differences in coordinate individual test points are provided in both directions, in meters, and we can see that the values of coordinate differences in the $\mathrm{Y}$-axis (E) ranging from 7,829 to -12.387 meters, while the $\mathrm{X}$-axis (N) range from 14,288 to -8.467 meters.

Based on the obtained results of DTM25 positional accuracy evaluation, the value of circular map accuracy standard (CMAS) is 7,785 meters, and since the value of the CMAS is less than 12.5 meters (CMAS $<12.5 \mathrm{~m}$ ) it can be concluded that the test map belongs to the best " $\mathrm{A}$ " map class according to the classification STANAG 2215 standards.

Figure 2 shows a map with test points in the assessment of horizontal positional accuracy for a specified test area. These test points are symbolized by different sizes of topographical indications in reliance to the middle of the square root of the horizontal position, as well as the modelled values of root middle horizontal position geostatistical interpolation method - Ordinary Kriging.

\section{CONCLUSION}

The purpose of describing the quality of spatial data is to present its ability to allow the comparison and selection 
of data that best suits the needs, application or customer requirements. A complete description of the quality of data shall encourage the sharing, exchange and use of appropriate spatial data sets [5].

The knowledge of positional accuracy has funda- mental importance for map users and its manufacturers. Unlike most map properties, its horizontal positional accuracy can be fully examined and quantified in an exact way. This paper presents one of the possibilities of presenting results of an assessment of positional ac-

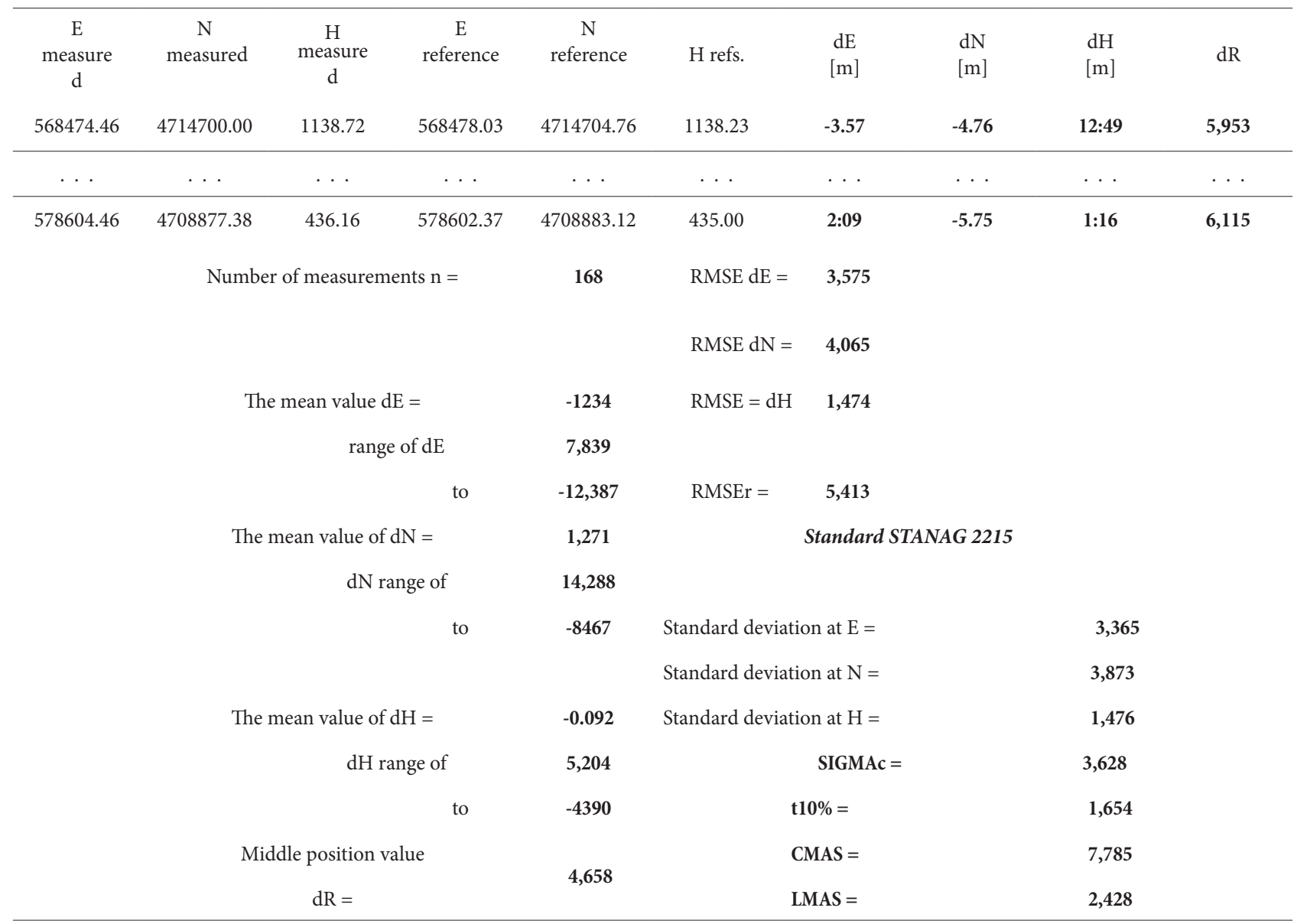

Table 1. Positional accuracy Assessment of the sheet DTM25 NK34-5/6-2-4 Vranje.

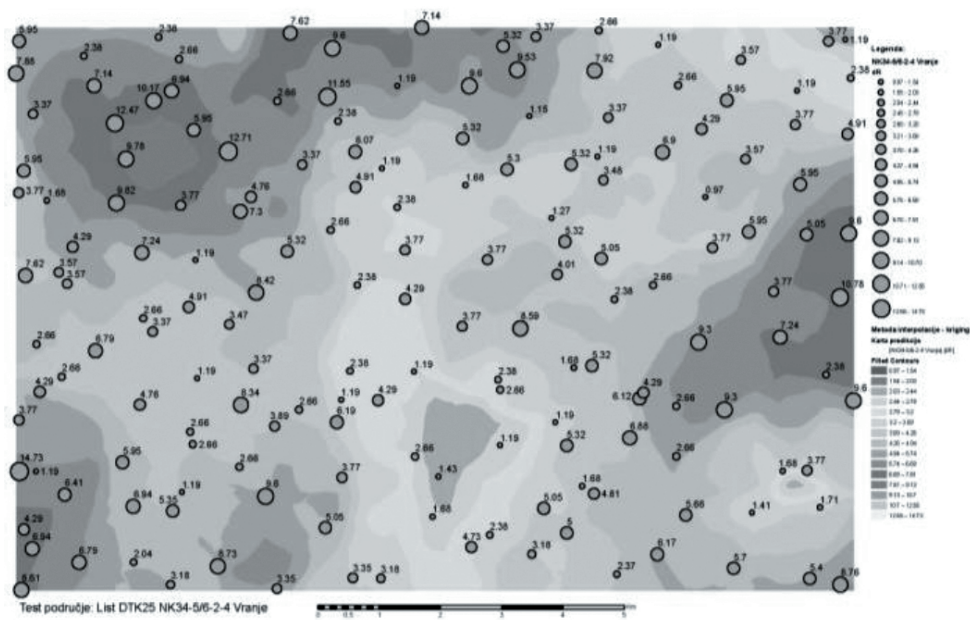

Fig. 2. Visual display of horizontal positional accuracy assessment results of the sheet DTM25 NK34-5/6-2-4 Vranje. 
curacy of digital topographic maps, scaled at 1:25 000, using a geostatistical interpolation method, such as the Ordinary Kriging.

\section{REFERENCES}

[1] Ariza López,F.J.\&Atkinson Gordo,A. D. (2008). Analysis of some positional accuracy assessment methodologies, Journal of Surveying Engineering, 134(2), 45-54, 2008.

[2] Ariza-López, F. J., Mozas-Calvache, A. T., UreñaCámara, M. A., Alba-Fernández, V., García-Balboa, J. L., Rodríguez-Avi, J., and Ruiz-Lendínez, J. J.,(2011). Sample size influence on line-based positional assessment methods for road data. ISPRS Journal of Photogrammetry and Remote Sensing 66: 708-19

[3] Božić, B., Radojčić, S., (2011). Horizontal accuracy of 1:50 000 digital topographic maps, Survey Review, 43, (94-104), Bristol (United Kingdom).

[4] Devillers, R.\& Jeansoulin, R. (2006).Spatial Data Quality: Concepts, In Fundamentals of Spatial Data Quality, edited by R. Devillers and R. Jeansoulin. London: ISTE, pp. 31-42.

[5] Drobnjak, S., Radojčić, S., Božić, B., (2014).ISO 19157 standard application in tehnological process of the production of digital topographic maps, Tehnika, vol.66, num.4, pg. 551-556.

[6] Drobnjak, S., Sekulović, D., Amović, M., Gigović, Lj. \& Regodić, M., (2016). Central geospatial database analysis of the quality of road infrastucture data, $\mathrm{Ge}$ odetski vestnik, ISSN 0351-0271, EISSN 1581-1328, DOI:10.15292/geodetski-vestnik.2016.02.270-285, Volume 2, pg. 270-285, Ljubljana, Slovenia.

[7] Drummond, J., (1995).Positional accuracy, in Elements of Spatial Data Quality, edited by Guptill, S. C.And Morrison J.L., Oxford, Elsevier, pp. 31-58.

[8] Esri ArcGIS 10.2. (2014).Positional Accuracy Assessment Tool Help, 380 New York Street, Redlands, CA 92373-8100, USA, 2014.
[9] Fisher,P.F., ComberA.J. and Wadsworth,R.A. (2006). Approaches to uncertainty in spatial data, In Fundamentals of Spatial Data Quality, edited by R. Devillers and R. Jeansoulin. London: ISTE, pp. 43-59, 2006.

[10] FGDC,(1998). FGDC-STD-007: Geospatial Positioning Accuracy Standards; Part 3, National Standard for Spatial Data Accuracy. Reston, VA, Federal Geographic Data Committee

[11] Goodchild, M. F. and Hunter, G. J.,(1997). A simple positional accuracy measure for linear features. International Journal of Geographical Information Science 11: 299-306

[12] Hengl, T. (2007). A practical guide to geostatistical mapping of environmental variables (Vol. 140, No. 4, pp. 417-427).

[13] Isaaks, E., Srivastava, M. (1989). Applied Geostatistics, New York, Oxford University Press.

[14] ISO (19157). The International Organization for Standardization, ISO 19157: Geographic information - Data Quality; Geneva.

[15] NATO (2002). Standardization Agreement (STANAG) 2215: Evaluation of Land Maps, Aeronautical Charts and Digital Topographic Data, Edition 6, NATO Standardization Agency, Brussels.

[16] Servigne S., Lesage N. and Libourel T. (2006). Quality Components, Standards, and Metadata, In Fundamentals of Spatial Data Quality, edited by R. Devillers and R. Jeansoulin. London: ISTE, pp. 179-208.

[17] Skidmore, A. and Turner, B.,(1992). Map accuracy assessment using line intersect sampling. Photogrammetric Engineering and Remote Sensing 58: 1453-57

[18] Tveite, H. and Langaas, S.,(1999). An accuracy assessment method for geographical line data sets based on buffering. International Journal of Geographical Information Science 13: 27-47

[19] USBB,(1947). United States National Map Accuracy Standards. Washington, DC, US Bureau of the Budget. 


\section{VISUALIZATION OF HORIZONTAL POSITIONALACCURACY ASSESSMENT RESULTS FOR DIGITAL TOPOGRAPHIC MAPS AT SCALE 1:25000}

\begin{abstract}
Rezime:
U radu je opisana mogućnost vizualizacije dobijenih rezultata ocene horizontalne položajne tačnosti digitalne topografske karte razmera 1:25 000 (DTK25) korišćenjem geostatističkih metoda interpolacije. Ocena horizontalne položajne tačnosti DTK25 realizovana je na osnovu standarda STANAG 2215 (eng: Standardization Agreement), koji je namenjen izdavačima geotopografskog materijala, odnosno nacionalnim kartografskim agencijama za ocenu horizontalne i vertikalne položajne tačnosti prostornih podataka, korišćenjem softvera ArcGisfirme ESRI. Rezultati ocene horizontalne položajne tačnosti prikazani su pomoću karte sa interpolovanim vrednostima korena srednjeg horizontalnog položaja.
\end{abstract}

Ključne reči:

Kvalitet prostornih podataka, položajna tačnost, STANAG 2215, metode interpolacije, kriging. 